\title{
Jacques Kornberg \\ The Pope's Dilemma: \\ Pius XII Faces Atrocities \\ and Genocide in the Second World War
}

(Toronto: University of Toronto Press, 2015), $x+405$ pp.

\author{
DAVID I. KERTZER \\ david_kertzer@brown.edu \\ Brown University, Providence, RI 02912
}

The defense of Pope Pius XII (1939-58) for his refusal to publicly condemn Nazi Germany and its allies for their mass murder of Europe's Jews and for the other atrocities they committed finds a rather unorthodox champion in Jacques Kornberg. Taking advantage of the large scholarly literature on the topic, in The Pope's Dilemma Kornberg systematically examines the pope's actions during the Second World War, placing them in the context of then prevailing Catholic theology and papal precedent. On the one hand, he deems the pope a "moral failure" for having adopted a policy of "calculated acquiescence" to Nazism. Yet, at the same time, he argues that Pius XII, like his most recent predecessors, fulfilled his role as pope "in exemplary fashion" (p. 5).

Kornberg begins the book by examining the precipitous fall in Pius XII's reputation. He links this to Rolf Hochhuth's play, "The Deputy," which opened in Berlin in 1963, with its charge that the pope knew of the slaughter of Europe's Jews but failed to speak out against it. The resulting storm of criticism over Pius XII's papacy came, not coincidentally, as the Catholic Church was being transformed by John XXIII's papacy and the Second Vatican Council. To many, Pius came to incarnate a medieval church mired in antisemitism and authoritarianism. Even after the war, Pius never spoke out against antisemitism or acknowledged any Church responsibility for the demonization of the Jews. His continual selfcongratulations for his self-described heroic efforts in rescuing Jews further fed critical views of the wartime pope.

In the following chapters, Kornberg reviews the evidence not only of Pius XII's wartime behavior, but also of how his two immediate predecessors handled major wartime human rights abuses. He finds that Benedict XV (1914-22) failed to condemn either German atrocities against Belgians during the First World War or the Turkish genocide against Armenians. Likewise, he points out that while Pius XI (1922-39) opposed Mussolini's war in Ethiopia, he refused to publicly condemn it once it had begun. From these precedents, he concludes that "papal 
responses to twentieth-century atrocities followed an unvarying pattern" (p. 220). In Kornberg's view, Pius XII's guiding principle, like that of his predecessors, was to avoid condemning Catholics for committing war crimes "so as not to alienate them from the church" (p. 235).

While Kornberg defends Pius XII from some of his harshest critics, he gives no comfort to the pope's most ardent defenders. He demolishes the commonly heard argument that Pius XII kept quiet about the unfolding mass murder of Europe's Jews out of concern that he would make matters worse for them by speaking out. Among the arguments he shreds by a look at the historical evidence is the claim that the case of the Nazi deportation of the Dutch Jews showed that any protests by the pope would be counterproductive.

As Kornberg argues, Pius XII stood by the view even after the war that "German Catholics were untarnished by National Socialism" and that, indeed, Germany's Catholics had "stood firm and resisted the Nazis" (p. 26). What most worried him during the war was not the slaughter of Europe's Jews but the possibility that if he were to do anything to denounce publicly the genocide he would risk losing the loyalty to the Church of Catholics who supported the Nazis and took part in their crimes. Devoting a chapter to Poland, where not only Jews but many priests and bishops were murdered, Kornberg concluded that for Pius XII, "it turned out that it was easier ... to appease Catholics engaged in war crimes by publicly saying nothing, than [to speak up for] Catholic victims of war crimes, who demanded he say something" (p. 142). Pius XII became expert at expressing lofty sentiments in a sufficiently abstruse way to permit him to deny his comments were aimed as criticism of anyone in particular.

The pope, as Kornberg rightly states, had no sympathy for Nazism. In dealing with Hitler, Kornberg argues, he was following in his predecessors' footsteps. All felt more comfortable with authoritarian regimes than with parliamentary democracies and were willing to make deals with any regime in order to win freedoms for the Church. Here he cites Leo XIII (1878-1903) and his dealings with the French Republic as an example.

Kornberg maintains that Pius XII should not be judged by human rights principles that influenced Catholic thought only after the Pope's death. "The retreat of Pope Pius XII before radical evil had deep roots in Catholic doctrines," Kornberg insists (p. 265). Indeed, he argues that Pius XII should be judged a success as a pope, "for he steered the Roman Church intact though stormy seas." However, Kornberg points out that this does not mean accepting the claim, made first by the pope himself, that he merited praise as a moral authority. Here, Kornberg argues, "an immense gap existed between his claims and reality" (pp. 297-98).

The Pope's Dilemma offers a useful guide through the enormous literature on Pius XII and the Second World War published in English, French, and German, as well as a provocative thesis regarding how the pope's behavior should be judged. A failure to use Italian sources-given that this was Pius XII's language and the language of almost all Vatican diplomatic correspondence-means that there is likely much to be learned in pursuing Kornberg's aim of penetrating the pope's mind. Yet, for this reviewer, by clearing the ground of baseless claims 
about the pope, Kornberg has helped clarify the highly consequential historical and moral issues at stake in evaluating this controversial pontiff. 